\title{
The Intermarriage Life Satisfaction Premium
}

\author{
Gina Potarca ${ }^{1} \cdot$ Laura Bernardi $^{2}$
}

() Springer Nature B.V. 2020

\begin{abstract}
Research on the consequences of intermarriage is almost exclusively looking at immigrants' labour market outcomes, with little attention given to non-economic indicators. Drawing from set-point theory and taking on a dynamic approach, the authors examine whether having a different- versus a same-origin partner is subject to a selection on life satisfaction, or associated with a greater short-term improvement in migrants and natives' subjective well-being (SWB). The paper also aims to investigate whether gains from exogamy diminish at a faster rate than those from endogamy, and whether intermarriage produces a long-term drop in SWB. Using data from the German Socio-Economic Panel and controlling for time-varying unobserved heterogeneity, we run a set of random- and fixedeffects models that uncover changes in life satisfaction before and after the transition into a mixed marriage. Results provide evidence of a selection on life satisfaction for exogamous first generation migrant men. Findings also show that with the exception of migrant men, there is an inter-partnering SWB gain, albeit insignificant, in the pre-marital cohabitation phase. Native women display an intermarriage premium when transitioning to marriage and shortly after, but also a significant SWB drop in later years. Overall, contrary to previous studies that did not account for unobserved characteristics, we show that in the long run, mixed marriages are not more detrimental to SWB than unions involving same-origin partners.
\end{abstract}

Keywords Mixed union · Life events and/or transitions $\cdot$ Subjective well-being

\section{Introduction}

For immigrants, transitioning into a marital union with a native is seen as solid proof of assimilation (Alba and Nee 2005; Gordon 1964). Given the increase in mixed unions over the past years (Lanzieri 2012), and the continued rise in immigrant populations across most

Electronic supplementary material The online version of this article (https://doi.org/10.1007/s1090 2-020-00278-w) contains supplementary material, which is available to authorized users.

Gina Potarca

gina.potarca@unige.ch

1 NCCR LIVES, University of Geneva, Geneva, Switzerland

2 NCCR LIVES, University of Lausanne, Lausanne, Switzerland 
Western countries (OECD/EU 2015), understanding the extent to which having a differentversus a same-origin partner affects the individual well-being of a progressively large share of the population is a salient task. Empirical evidence on the rewards of inter-marrying remains limited (Kalmijn 2010). Most studies found that entering a union (either marital or cohabiting) with a native provides immigrants a premium, albeit not large, in terms of labour market performance (Baker and Benjamin 1997; Dribe and Lundh 2008), earnings' levels (Elwert and Tegunimataka 2016; Meng and Gregory 2005; Meng and Meurs 2009; Nystedt and Dribe 2015), or residential well-being (Ha et al. 2002).

However, what remain unclear are the effects of exogamy (i.e., marrying outside one's ethno-racial or origin group) on other non-economic aspects, such as subjective well-being (SWB), known to predict longevity, physical health (Diener and Chan 2011), as well as immigrant integration (Heizmann and Böhnke 2018). The few studies that examined the link between inter-partnering and psychological health primarily focused on SWB comparisons between people in different relationship configurations (e.g., Barr and Simons 2014; Bratter and Eschbach 2006; Fu et al. 2001; Hohmann-Marriott and Amato 2008), rather than selectivity or processes unfolding over time within and across such unions. The literature has also rather one-sidedly looked at the consequences of mixed unions for immigrants only, neglecting the potential premiums bestowed upon native partners. A recent exception is the study by Milewski and Gawron (2019), who analyze variation in depression for immigrants and non-immigrants in exogamous (i.e., different-origin) versus endogamous (i.e., same-origin) marriages. Nevertheless, the authors could not examine pre-partnering levels of mental health, and only focus on individuals 50 to 80 years old. Whereas endogamous partner choices still prevail in many European countries (e.g., Sweden: Behtoui 2010; Germany: González-Ferrer 2005; the Netherlands: Kalmijn and van Tubergen 2007), research looking at online dating preferences indicates that minority daters would rather be matched to a native than someone from the same group (Potârcă and Mills 2015). Natives' openness towards exogamous partners has also been increasing among younger cohorts (Carol 2016). Given such predilections, we seek to understand the (other than socio-economic) merits of exogamy, and the degree to which such partnerships contribute to changes in SWB for both immigrants and natives. Given inconsistent past findings (Fu et al. 2001; Van Mol and de Valk 2016), we also inquire whether intermarriage is experienced differently by men versus women.

The paper takes on a dynamic approach and analyzes the link between transitioning into a marital union with a different- versus a same-origin partner, and SWB changes across time. To this end, we use the framework of set-point theory (Suh et al. 1996), which asserts that SWB gains (or losses) inflicted by major life events are only transient, with individuals returning to a baseline level of SWB within a few years. Despite criticism and rebuttals (e.g., Zimmermann and Easterlin 2006), the theory remains influential in the literature on stability and change in individual well-being across the life course (Anusic et al. 2014);it also assists us in conceptualizing different phases in the union formation trajectory (i.e., pre-union, the immediate reaction, long-term adaptation). First, we scrutinize whether mixed unions are selective on pre-union (i.e., baseline) levels of SWB. Second, we assess the magnitude of the mixed union SWB premium (or penalty) across different stages, and ask the following questions: Is entering an exogamous union associated with a greater short-term improvement in SWB (i.e., reaction) compared to an endogamous union? Do the gains from intermarriage diminish at a faster rate than those from marrying someone from one's own group? Overall, does exogamy produce a long-term drop in life satisfaction or do all couples go through temporary changes to return to their set point (i.e., prepartnering) level of life satisfaction no matter what union type they entered? And finally, 
are there differences in such dynamics between migrant and native partners, and across gender? Through these inquiries, we aim to analyze selection into intermarriage, incremental changes from stage to stage, as well as a long-term evolution in SWB for exogamous versus endogamous couples. The analysis relies on detailed samples of migrant and native respondents from the German Socio-Economic Panel (SOEP). The prospective nature of the data allows us to examine the evolution of SWB over time by tracking changes in individuals' self-reported life satisfaction before and after entering a mixed union. We account for both observed selectivity (by examining pre-partnering levels of life satisfaction via random-effects modeling), and time-varying unobserved heterogeneity through distributed fixed-effects modeling. Even though cohabitation is a frequent substitute to marriage among Germans (Klärner and Knabe 2017), we restrict the analysis to married couples only due to the small number of cohabiting unions not ending in marriage in the sample. Finally, to account for the high prevalence of premarital cohabitation (Kasearu and Kutsar 2011), and the enhancing effect of cohabiting before marriage on life satisfaction (Zimmermann and Easterlin 2006), we include cohabitation as a pre-marriage stage. Isolating individuals' SWB when single versus when cohabiting before marriage also allows us to disentangle selection (i.e., innately high levels of SWB) from anticipation (i.e., SWB increasing as the time of marriage approaches) effects.

Though this study defines mixed marriages as unions between individuals with immigrant background (of both first and second generation) and natives (i.e., born in Germany to non-migrant parents), we also use arguments from and refer to the literature focusing on other types of mixed partnering, such as inter-racial (e.g., Kalmijn 1993) or inter-ethnic unions (e.g., Fu 2001) in the U.S. We acknowledge that racial boundaries in the U.S. are anchored in an idiosyncratic racial past and may differ from boundaries separating immigrants and non-immigrants in Germany. Nevertheless, we argue that bridging cultural divisions in marrying someone outside of one own's racial or origin group may pose similar challenges. Furthermore, even though a large part of second generation respondents (i.e., children of immigrants) were born in Germany, are often German citizens, ${ }^{1}$ and have no direct experience of migration, we include them in the same category as the first generation given the still persistent cultural gap between descendants of immigrants and natives. Along with inheriting the economic and residential disadvantage of their parents as the result of enduring inequalities due to their origin (Algan et al. 2010; Drouhot and Nee 2019; McAvay 2018), second generation migrants also preserve and often even strengthen a non-native cultural identity (Çelik 2015; Galli and Russo 2019; Gerhards and Buchmayr 2018). We thus assume that, as with unions between first generation migrants and natives, marriages between second generation migrants and German natives also involve a certain level of intra-couple cultural asymmetry. Germany is a compelling case to examine the link between intermarriage and SWB. It has the largest immigrant population in the EU, with approximately $20 \%$ of its population consisting of residents that are either foreign-born or German-born with foreign parents (OECD/EU 2015). The post-war inflow of immigrants commenced in the mid-50s and 60s with the signing of guest-worker recruitment agreements between West Germany and various countries, starting with Italy in 1955 and continuing with, among others, Spain and Greece in 1960, Turkey in 1961, or Yugoslavia in 1968 (Milewski 2007). Though most migrant workers returned to their home country after the termination of recruitment programs in the $70 \mathrm{~s}$, many foreign workers with a job

\footnotetext{
${ }^{1}$ Legal status and access to citizenship varies among immigrant groups, with ethnic Germans generally the most favored in terms of integration assistance (Luthra 2013).
} 
were allowed to stay (Cyrus and Vogel 2005). In the following two decades, the population of residents with a foreign background was continuously enlarged through family reunification, immigration of ethnic Germans (Aussiedler) from Eastern Europe, as well as the arrival of refugees and asylum seekers from conflict stricken areas, including Turkey, exYugoslavia and other non-European countries (ib.).

Through the lens of a process perspective, this paper advances the literature by being the first to investigate mixed marriages as agents of SWB change (as opposed to SWB status) among both immigrants and natives. It also answers the need to examine psychological well-being with reference to not only individual stressors, but also to the gains or challenges that are unique to specific partnership arrangements (LeBlanc et al. 2015). This study also innovates by aiming to identify whether mixed unions are linked to a positive selection on life satisfaction. Except for research that addressed the selection of exogamous immigrants on economic characteristics (e.g., Nystedt and Dribe 2015), no study has so far tested the SWB selectivity of both migrants and natives who partner outside of their group. By comprehensively speaking of both selection and change in SWB, we therefore go beyond previous studies that dealt with cross-sectional associations only (e.g., Bratter and Eschbach 2006; Hohmann-Marriott and Amato 2008).

\section{Background and Hypotheses}

\subsection{Set-Point Theory}

Set-point theory, or adaptation theory, assumes that individuals have an inherently stable level of SWB, predominantly shaped by genetics and personality (Diener et al. 2006; Lykken and Tellegen 1996). While certain events trigger increases or decreases in SWB, disruptions are short-lived and people rapidly revert to their usual (i.e., baseline) level of well-being. The change occurring immediately after the event is referred to as reaction, whereas the return to the pre-event level of SWB is called adaptation. Research on fluctuations in SWB prompted by the transition to marriage based on panel data sources from various countries confirms that individuals display a boost around the time of marriage, but that they revert to baseline in the following two-three years (Anusic et al. 2014; Clark and Georgellis 2013; Lucas et al. 2003). Notwithstanding this within-person return to a pre-marriage state of SWB, between-person comparisons indicate that married individuals are better off than the continuously single, who, on the contrary, experience gradual declines in SWB.

Some studies dispute certain assumptions of set-point theory by claiming that adaptation can take much longer than predicted (Soons et al. 2009), or that individuals never experience a complete reversal to the pre-marriage point (Zimmermann and Easterlin 2006). Nevertheless, whether short- or long-term, there is widespread agreement that the transition to marriage, as well as the state of being married, has positive effects on SWB (Horwitz et al. 1996; Kim and McKenry 2002). The current study contends that the process of entering and staying in mixed unions presents a unique set of opportunities and challenges, inflicting added gains or strains to individuals' SWB when transitioning from one stage to another, as well as in the long-run (i.e., long-term change compared to pre-union levels). 


\subsection{Selection: Baseline Levels of SWB}

First though, both immigrants and natives who choose to intermarry may represent a select group of adults. For immigrants, some studies examining intermarriage premiums in terms of economic performance point to the existence of a heightened level of earnings already noticeable prior to marrying a native (Nystedt and Dribe 2015). However, we assert that intermarriage may be selective on higher levels of SWB independently from any socio-economic pre-union advantage, for both migrants and natives (hypothesis 1). Two mechanisms could explain why exogamous individuals might have higher baseline life satisfaction compared to the endogamous. First, given the positive association between SWB and general openness to experience (Heidemeier and Göritz 2016; Suldo et al. 2015), happier people may be more likely to choose a partner beyond one's own group. Second, high SWB also drives the capacity to build and sustain rich social networks (Diener and Seligman 2002; Guven 2011). What follows is that adults with high baseline levels of SWB might be more prone to meet and partner people outside of their own group due to wider dating pools. With reference to migrants only, individuals with a high level of life satisfaction tend to stay longer (Massey and Akresh 2006; Shamsuddin and Katsaiti 2019), and have a greater sense of belonging to the host country (Amit and Bar-Lev 2015). High SWB immigrants, with a greater self-perceived attachment to the native mainstream, could not only be more willing to choose a native partner, but due to better integration, they would also be more likely to be chosen by natives themselves. In most Western European countries, migrants belonging to the first generation are less prone to marry natives (González-Ferrer 2005; Hannemann et al. 2018; Safi 2010a). This means that those who do enter exogamous unions with natives are likely a more select group, for whom a high SWB, which could make up for lower mate value (e.g., greater cultural distance from native mainstream), may be already noticed prior to union formation. The second generation, on the other hand, may be less dependent on this particular source of attractiveness. Finally, compared to migrant women, migrant men marry exogamously less often (Lanzieri 2012; Safi 2010a, b), and face a greater shortage of marriage candidates particularly in the first waves of immigration (Donato et al. 2011). Given that a high SWB could compensate for other unfavorable characteristics on the marriage market, we expect hypothesis 1 (higher baseline level of life satisfaction when partnering exogamously versus endogamously) to be particularly valid in the case of first generation migrant men (hypothesis 1.1).

\subsection{Reaction Effects}

Furthermore, we argue that besides the emotional benefits experienced as short-term reaction to union formation in general, individuals entering mixed unions receive a supplementary improvement in SWB. Life satisfaction gains during the so-called "honeymoon phase" could be greater for exogamous than culturally homogenous couples, given that in the incipient stages of a union, intermarried partners tend to perceive cultural mixedness as an asset, both positive and enriching (Singla and Holm 2012). As opposed to later stages in the relationship, the cultural adjustments that partners make in this initial phase are not only hardly regarded as difficulties, but they are infused with a sense of novelty and excitement (ib.). The life satisfaction premium conferred by having a different- rather than a same-origin partner in the early stages of a union would also result from the anticipation of starting to build a "we" that transcends group boundaries (Özateşler-Ülkücan 2019; 
Seshadri and Knudson-Martin 2013). A distinctively greater focus on commonalities at the onset of a mixed partnership (Killian 2001; Özateşler-Ülkücan 2019) could provide bicultural couples increased life satisfaction. We thus expect that in the early stages of entering a union such increase is larger for exogamous than endogamous couples (hypothesis 2).

As previously noted and similar to Zimmermann and Easterlin (2006), we consider premarital cohabitation as first step in the reaction phase, alongside the subsequent short period occurring within the first two years of marriage (i.e., post-marital reaction). Given the much stronger legal implications of getting and staying married with a foreign-origin partner (de Valk and Medrano 2014), and the generally smaller boost in life satisfaction that premarital cohabitation versus marrying triggers (Zimmermann and Easterlin 2006), we expect the interpartnering premium (i.e., the greater short-term gain in life satisfaction for exogamous than endogamous couples) to be larger when transitioning to marriage compared to entering premarital cohabitation (hypothesis 3). Especially for immigrants, marriage with a native reflects better integration, and should thus yield more life satisfaction than simply residing with a native partner without the legitimization of a marital contract.

Marrying exogamously however may have a stronger enhancing effect on life satisfaction in the short run for migrants than natives. Given the use of partner's resources, including an easier access to local networks (Scott and Cartledge 2009), matching with a native might further improve migrants' social, cultural, and economic adaptation to the host country (e.g., Dribe and Lundh 2008; Nystedt and Dribe 2015). Enhanced integration increases migrants' life satisfaction (Angelini et al. 2015), which should add to the previously described SWB premium resulting from being part of a culturally rich mixed union. Evidence also shows that in bi-national unions in the Netherlands for instance, it is foreign (and not native) partners that report greater relationship satisfaction compared to individuals in uni-national (i.e., Dutch-Dutch) unions (Van Mol and de Valk 2016). Within the non-native group, as migrant women generally experience worse social integration and have a more disadvantaged position on the labor market than migrant men (Elgorriaga Astondoa et al. 2020; Grigoleit-Richter 2017; Mushaben 2009), the former may have more to gain from matching with a native in the initial stages of inter-partnering than the latter. We thus hypothesize that in the short-term, exogamy improves individuals' SWB more than endogamy, especially in the case of migrant women (hypothesis 4).

\subsection{Adaptation Effects}

Set-point theory suggests that, in the long run, after the reaction effects of getting married fade away, people revert to a pre-union level of SWB (Lucas et al. 2003). Nevertheless, there is acknowledgement that individuals differ in whether and how adaptation unfolds (Diener et al. 2006), and that the return to baseline levels of SWB may depend on the interplay between personal resources, and how challenging the event or transition in question is (Cummins et al. 2014; Weinberg et al. 2016). Because of differences in conjugal strain between endogamous and exogamous couples, we anticipate different time spans of adaptation. For natives and migrants in endogamous marriages, we predict no long-term change in SWB (compared to baseline). For those in mixed unions however, we expect a much steeper drop in life satisfaction from early to later years of marriage (hypothesis 5), leading to an overall long-term negative change in SWB (hypothesis 6). There are at least two reasons why in the long-term, mixed marriages might be more harmful to partners' SWB than endogamous marriages. First, as 
the relationship reaches maturation and disagreements accumulate, cultural differences that were once celebrated become emotionally challenging over time (Singla and Holm 2012). Partners from dissimilar backgrounds grapple with negotiating a coherent set of shared preferences, or providing a reciprocal confirmation of values and identity (Dribe and Lundh 2011). There are several studies in support of the exogamy-strain hypothesis (Milewski and Gawron 2019). In the U.S., individuals in interracial unions reported higher levels of distress and depressive symptoms, lower levels of relationship satisfaction (Bratter and Eschbach 2006; Fu et al. 2001; Hohmann-Marriott and Amato 2008; Kroeger and Williams 2011), a greater incidence of intimate partner violence (Martin et al. 2013), and higher union dissolution risks (Bratter and King 2008). Second, social and family-related pressure still impacts partnering practices, including the choice of marrying outside group boundaries (Yahirun and Kroeger 2019). Given the enduring stigma of intermarrying (Rodríguez-García et al. 2016), the often arduous relations with family and in-laws (McNamara et al. 1999), or the general lack of social support (Bratter and King 2008; Kroeger and Williams 2011), exogamy might be ultimately experienced as more strenuous than endogamy. On the one hand, as they are more susceptible to the negative appraisal of their union (Van Mol and de Valk 2016), and have a greater geographical proximity to family and friends (particularly when compared to first generation migrants), we may expect a greater long-term negative effect of exogamy on SWB for German natives than for migrants. Milewski and Gawron (2019) for instance found that nonmigrants married to migrants reported higher levels of depression compared to those in endogamous marriages. On the other hand, in the asymmetry of conjugal mixedness, the native partner retains the cultural legitimacy of belonging to the majority group in addition to privilege and greater socioeconomic resources. The migrant partner is conversely out of the norm (Collet 2015), more perceptive of social disapproval (Killian 2001), at a greater risk of experiencing social loneliness (Koelet and de Valk 2016), and thus more vulnerable to the potentially disruptive effects of exogamy on SWB.

Finally, we anticipate certain differences in how men and women experience intermarriage in the adaptation stage. Some studies encountered no gender differences in how mixed unions affect SWB (e.g., Hohmann-Marriott and Amato 2008; Troy et al. 2006; Van Mol and de Valk 2016). Others however concluded that being in a mixed union is more consequential for women, who are more susceptible to the disapproval of their union by family and community, and hence more negatively affected by the pitfalls of inter-partnering than men (e.g., Fu et al. 2001). Gender also influences the way exogamous partners adjust to one another, with women believed to adopt the cultural practices of their different-origin spouse to a greater extent than men (Collet 2015). After honeymoon effects fade away, unequal power dynamics and the greater mental load of cultural adjustment could lead to a potentially greater negative effect of intermarriage on SWB for women compared to men in both the short run (i.e., difference between adaptation and reaction) and the long run (i.e., difference between adaptation and baseline) (hypothesis 7). Here, we anticipate gender variation to be particularly evident among native women paired with migrant men (hypothesis 7.1). Native women, embedded in their local networks, may need to invest a greater effort to adapt to a migrant partner than migrant women (already integrating into the native mainstream) paired with native men do. This means that the exogamy versus endogamy difference in the short-term and long-term drop in life satisfaction would be greater in unions between native women married to migrant men, than in unions between migrant women married to native men. 


\section{Data and Method}

\subsection{Sample}

This study uses data from 31 waves (1984-2014) of SOEP (version 31, 2016, http://www. diw.de/en/diw_01.c.492248.en/soep_v31ibeta.html), a large-scale representative sample of the German adult population living in private households with a yearly re-interview design (Wagner et al. 2007). One of the longest running panels, the SOEP was initiated in 1984 in West Germany, with East German regions joining in 1991. In 1994-95 an additional subsample of approximately 500 households with at least one member who entered West Germany after 1984, and in 2013 another supplementary sample of around 500 households with migrants arriving to Germany after 1995 were included, to ensure a substantial representation of an increasing first- and second generation immigrant population. Having reinterview response rates consistently above 0.870 (Schoeni et al. 2013), and an individuallevel attrition rate smaller than other panels, i.e., below 0.1 (Lipps 2009), SOEP provides a sample size large enough to allow for the examination of trajectories of SWB both before and after union formation. We selected respondents who entered the panel as un-partnered ${ }^{2}$ and followed them as they transition into marriage, but also included participants in the pre-marital cohabitation or reaction phase of the marital trajectory (i.e., recently married) when first observed, and who transitioned into marriage or the adaptation stage of marriage, respectively. Furthermore, we kept respondents who participated in the panel at least twice (the average number of participation waves is 9.08 for migrants and 9.29 for natives), and who had valid information on all variables of interest. Similar to previous work (Brüderl and Ludwig 2015; Nystedt and Dribe 2015), we chose a time window no larger than ten years before and ten years after the year of marriage, and censored observations upon widowhood or relationship dissolution. After also excluding respondents younger than 18 , the final sample included $N=1,529$ migrants with 13,591 person-years, and $N=5,920$ natives with 54,092 person-years. Given the possibility of selective union dissolution among intermarried individuals with low levels of life satisfaction, we ran sensitivity analyses (see Supplementary Material) with a shorter adaptation window of five years after union formation (very few dissolution occur before this duration). The results are almost identical to the ones estimated with marriage durations of ten years, suggesting that there is no selective marriage dissolution based on life satisfaction.

\subsection{Measurement of Variables}

The dependent variable is measured via global life satisfaction, which represents an overall cognitive evaluation of life, and is extensively used in studies on life course transitions and SWB (Luhmann et al. 2012). Life satisfaction is a relatively stable construct (Eid and Diener 2004), but evidence also indicated its reactivity, both short-term and long-term, to changing circumstances and relevant life events (e.g., Myrskylä and Margolis 2014). SOEP provides annual data on life satisfaction using the following item: "How satisfied are you

\footnotetext{
${ }^{2}$ We exclude observations of respondents dating a partner (i.e., being part of a non-residential relationship) to avoid that the baseline category is not "contaminated by the happy period during which friendship with the eventual marriage partner is being developed and enjoyed" (Grover and Helliwell 2019, 375).
} 
with your life, all things considered?" Respondents answer on an 11-point Likert scale ranging from 0 (completely dissatisfied) to 10 (completely satisfied).

Information on the year of partnering is derived from biographical information on marriage and cohabitation entry and when missing, from between-wave changes in partnership and marital status. In case there is more than one transition observed per individual, we include all partnership spells (with different partners) experienced by the respondent. Nevertheless, if the respondent separates from their spouse for a certain number of years and subsequently re-partners with the same person, only the first spell is considered. To examine a more detailed time profile of satisfaction and see how the outcome variable varies not only at time of (inter)partnering, but also before and after entering the union, a marital trajectory variable is constructed. It denotes four key phases: $1=$ baseline (i.e., the un-partnered phase, lasting 3.35 years on average for migrant respondents, and 2.87 for natives); 2 =premarital cohabitation (from the year when partners move in together until the moment they marry, with an average of 2.73 years spent in this stage for migrants and 3.00 for natives); $3=$ reaction (consisting of the first year of marriage and the year immediately after, with an average of $1.41^{3}$ years spent in this stage for migrants and 1.47 for natives); and $4=$ adaptation (i.e., denoting the period starting two years and up to ten years after union formation, with the average being approximately 4.24 for migrants and 4.22 for natives). This manner of conceptualizing time before and after entering a committed union, and the allocation of, for instance, two years for the reaction phase, follow the strategy used in previous studies in the field (e.g., Zimmermann and Easterlin 2006).

Furthermore, origin is captured by using information on whether there is a migratory background, country of birth, and current nationality recorded in the first year of participation in the panel. Migratory background is pre-constructed and readily available in the SOEP data set, being largely based on information on either the nationality or the country of origin of the parents. Respondents are considered as having a migration background when at least one of their parents is of immigrant origin (i.e., non-German national or born outside Germany), irrespective of the individual's current nationality, age of arrival or whether born in Germany. Naturalized respondents with non-German parents for instance qualify as individuals with (indirect) migratory background. When the origin of parents is not given, which is the case for $6.1 \%$ of all SOEP participants, the variable employs time-variant information on previous and current nationality, specifically data on whether the respondent has or had a non-German citizenship. Based on this and previous items, we construct the origin factor, as follows: (1) individuals with current German nationality, who were born in Germany, and have no migratory background, are coded as "native"; (2) respondents with migratory background are assigned their country of birth (if born abroad) or their non-German nationality (if born in Germany and naturalized) as origin. The study distinguishes between five broad migrant groups: Turks, ex-Yugoslavs, Southern Europeans (including respondents of Italian, Spanish, Portuguese, or Greek descent), Eastern Europeans, and others. Union type is subsequently coded as endogamous if respondents' and their partners' origin match, or exogamous if their origins are different. For migrants, we only consider exogamous unions that involve native partners, given the small number of observed partnership transitions involving migrants from another group than their own.

\footnotetext{
3 The average is less than two given that some respondents for instance entered the observation window in the second year of marriage.
} 


\subsection{Control Variables}

To account for the socio-demographic selectivity of partnered respondents, the study includes several factors that could also drive within-variation in SWB, such as: employment (Oesch and Lipps 2013), differentiating between full-time employed, part-time working, unemployed, or not working; household income (Angelini et al. 2015) in logarithm form; age (ib.); and survey period. We acknowledge the impact of the transition to parenthood on SWB (Myrskylä and Margolis 2014) by controlling for number of resident children. Given sample size limitations (e.g., as information on first births for men is available since 2001 only, running analyses on this sub-sample only would significantly truncate our sample of exogamous unions), we cannot account for detailed parenthood effects.

In random-effects models we also include the following time-constant covariates: education, ${ }^{4}$ whether previously married, migrant origin, and generation type. Education differentiates between: low (respondents with at most general elementary school, basic vocational qualifications, or those that are still in school); medium (general or vocational intermediate qualifications, or maturity certificates); and high level (tertiary education). Generation type distinguishes between first (respondents who migrated after the age of six), and second generation (non-native individuals that either migrated before the age of six, or were born in Germany). The second generation category essentially includes children of immigrants born in Germany or having arrived before entering formal education. We also considered an alternative operationalization including a ' 1.5 generation' category (i.e., respondents who came to reside in Germany between the ages of six and 16), but the sub-sample was limited. Accounting for the duration of migration among first generation respondents (i.e., distinguishing between recent and established migrants) has little effect on life satisfaction, and does not affect the magnitude nor direction of main effects (results available from authors).

\subsection{Analytical Approach}

First, to examine between-subject variation in pre-partnering levels of life satisfaction we estimate multilevel random-effects linear models (Snijders and Bosker 2011). The analysis is ideally suited to test hypothesis 1 concerning SWB differences between exogamous and endogamous respondents at baseline. The models also account for the non-independence of observations within each person by nesting measurement occasions (i.e., level one) within individuals (i.e., level two).

The specification takes the following mathematical form:

$$
\mathrm{y}_{i, t}=\alpha+\sum_{k=0}^{3} T_{i t}^{k} \theta_{k}+\sum_{k=0}^{3} T_{i t}^{k} \gamma_{k} \times \operatorname{exogamy}_{i}+\sum_{j} C_{j, i,(t)} \beta_{j}+u_{i, t}
$$

where $\mathrm{y}_{i, t}$ is the life satisfaction level of respondent $i$ at time $t$, modeled as a linear function of the four stages of marital trajectory $\left(\sum_{k=0}^{3} T_{i t}^{k} \theta_{k}\right) . T_{i t}^{0}$ equals one for year $t$ spent by respond-

\footnotetext{
${ }^{4}$ Given considerable within-individual missing values on educational level, we did not consider education as time-varying and preferred a time-constant measure, which is less afflicted by missingness. Adding time-varying education as covariate in analyses on a trimmed sample also does not alter the direction and magnitude of our main effects.
} 
ent $i$ as non-partnered (i.e., baseline). Similarly, $T_{i t}^{1}$ equals one for time spent in premarital cohabitation, $T_{i t}^{2}$ equals one for the first two years after union formation (i.e., reaction), and $T_{i t}^{3}$ is one for time spent in the subsequent adaptation phase. $\theta_{k}$ denotes the average life satisfaction experienced during phase $k$ compared to the average life satisfaction at baseline. When adding the interaction between time in each trajectory stage and an indicator of exogamy, $\theta_{0}$ for instance captures the life satisfaction level at stage $k=0$ (i.e., baseline) for endogamous individuals, whereas $\gamma_{0}$ provides the difference in set-point for exogamous respondents. $C_{j, i,(t)}$ represents a vector of either time-constant or time-varying covariates $j$ measured at each time $t$ for respondent $i$. Finally, $\alpha$ represents the overall constant term, whereas $u_{i, t}$ is a person-specific random error term that summarizes all of the unobserved characteristics of respondent $i$, and that is assumed to be unrelated to any covariate. The model that tests the validity of hypothesis 1.1 (suggesting that selection is stronger among first generation migrant men), includes an extra three-way interaction of time, type of union, and gender $\left(\sum_{k=0}^{3} T_{i t}^{k} \gamma_{k} \times\right.$ exogamy $_{i} \times$ female $\left._{i}\right)$; the analysis is also stratified by generation type.

Second, to examine intra-individual variation in life satisfaction and test subsequent hypotheses focusing on change between different stages in the marital trajectory, we rely on distributed fixed-effects linear models (Dougherty 2006) that distinguish between the four key phases before and after the transition into an exogamous versus endogamous union. Compared to the basic fixed-effects estimation, which only accounts for unobserved confounding (Allison 2009), this approach also considers unobservables as subject to change over time. In other words, it tackles both the unobserved selectivity of (inter-)partnering, and the change in the effect of partnering on SWB across different time periods. Both the random-effects and the fixed-effects estimations additionally work well with the unbalanced nature of the panel (i.e., different number of observations within individuals).

The fixed-effects model can be illustrated as follows:

$$
\mathrm{y}_{i, t}=\sum_{k=0}^{3} T_{i t}^{k} \theta_{k}+\sum_{k=0}^{3} T_{i t}^{k} \gamma_{k} \times \operatorname{exogamy}_{i}+\sum_{j} C_{j, i, t} \beta_{j}+\alpha_{i}+\varepsilon_{i, t}
$$

As with Eq. 1, the model adds the interaction between trajectory stage and exogamy, meaning that $\theta_{k}$ captures the effects of partnering on life satisfaction at stage $k$ for endogamous unions, whereas $\gamma_{k}$ provides the extra effect (i.e., difference in union premium) of being part of an exogamous arrangement. $C_{j, i, t}$ constitutes a vector of time-varying covariates $j$ measured for respondent $i$ at time $t$. Finally, $\alpha_{i}$ encapsulates the unobserved timeconstant variables that drop out of the equation in the fixed-effects estimation, whereas $\varepsilon_{i, t}$ denotes the random error for individual $i$ at time $t$. When gender hypotheses are tested, the specification includes extra interaction terms by respondent $i$ 's gender, as follows:

$$
\begin{aligned}
\mathrm{H}_{i, t}= & \sum_{k=0}^{3} T_{i t}^{k} \theta_{k}+\sum_{k=0}^{3} T_{i t}^{k} \theta_{k} \times \text { female }_{i}+\sum_{k=0}^{3} T_{i t}^{k} \gamma_{k} \times \text { exogamy }_{i} \\
& +\sum_{k=0}^{3} T_{i t}^{k} \gamma_{k} \times \text { exogamy }_{i} \times \text { female }_{i}+\sum_{j} C_{j, i, t} \beta_{j}+\alpha_{i}+\varepsilon_{i, t}
\end{aligned}
$$

We account for the potential autocorrelation and heteroscedasticity of idiosyncratic errors by estimating panel-robust standard errors (Brüderl and Ludwig 2015). To visually grasp the magnitude of results (Bauer 2014), we report graphs rather than tables of regression 
coefficients. To directly assess whether SWB varies from stage to stage (i.e., within change), we also present tables with stage-by-stage differences in predicted means (estimated at averaged values of all covariates), for the total sample and by gender. We examine whether respondents experience an exogamy premium (or penalty) in each phase by reporting the contrast between exogamous and endogamous couples in each of these stage-by-stage differences (i.e., between variation in within changes).

\section{Results}

\subsection{Descriptive Results}

First, we address the socio-demographic composition of our migrant and native samples, by union type (Table 1). For time-varying factors, we report figures corresponding to the reaction stage (i.e., the first two years after marriage). For both migrants and natives, we observe that life satisfaction shortly after marrying was greater for respondents with a different-origin partner than those in endogamous arrangements. Unsurprisingly, given the prevalence of cohabiting before marrying among Germans (Kasearu and Kutsar 2011), premarital cohabitation is more often observed among migrants that marry exogamously (rather than endogamously), and natives that partner endogamously (rather than exogamously). A particular difference between migrant and native respondents is the mean age at union formation. Whereas endogamous migrants are on average 29.79 years old in the first two years following marriage formation, those that choose a native partner are much older (33.91 y.o.). Natives however are indistinguishably above 35 , irrespective of union type. Furthermore, Table 1 shows that migrants with a native partner are more often highly educated, whereas those in endogamous unions are much more likely to have low-level education. Compared to respondents with same-origin partners, migrants matched with natives mention slightly higher levels of household income. Finally, Table 1 indicates that Turks (and to a smaller degree ex-Yugoslavs) are more represented among migrants in endogamous unions, and that previously married migrants are more often part of exogamous than endogamous unions. Descriptive statistics by gender are reported in the Supplementary Material (Tables S01 and S02).

\subsection{Results of Random-effects Models}

Table 2 presents the results of four random-effects linear regression models of life satisfaction, for migrants (in general), first generation migrants, second generation migrants, and natives respectively. Recall that the study first hypothesized that exogamous migrants and natives would be selected on higher levels of SWB compared to individuals who eventually partner endogamously. The models include an interaction between type of marriage and union trajectory stage, meaning that the coefficient for exogamous union indicates whether exogamy is linked to a different baseline level of SWB compared to endogamy. Results do not seem to confirm hypothesis 1 for either migrants (in general) or natives.

Hypothesis 1.1 suggested that among migrants, first generation men might be particularly selected on SWB. The models stratified by migrant generation and including threeway interactions between union type, trajectory stage, and gender, revealed that first generation migrant men who eventually partner exogamously indeed have a significantly higher 
Table 1 Socio-demographic Composition of the Migrant $(N=1,529)$ and Native Sample $(N=5,920)$, by Union Type. Source: GSOEP, 1984-2014, version 31

\begin{tabular}{|c|c|c|c|c|c|c|}
\hline & \multicolumn{3}{|l|}{ Migrants } & \multicolumn{3}{|l|}{ Natives } \\
\hline & Endogamous & Exogamous & & Endogamous & Exogamous & \\
\hline $\begin{array}{l}\text { Life satisfaction (range } \\
0-10)[M(S D)]\end{array}$ & $7.48(1.83)$ & 7.68 (1.63) & $* *$ & $7.47(1.61)$ & $7.66(1.66)$ & $* *$ \\
\hline $\begin{array}{l}\text { Premarital cohabitation } \\
(\%)\end{array}$ & 9.7 & 49.5 & $* * *$ & 64.6 & 54.0 & $* * *$ \\
\hline Female & 47.5 & 50.2 & & 49.9 & 49.0 & \\
\hline Generation type (\%) & & & $* * *$ & & & \\
\hline First-generation & 68.4 & 56.3 & & & & \\
\hline Second-generation & 31.6 & 43.7 & & & & \\
\hline Origin group (\%) & & & $* * *$ & & & \\
\hline Turks & 48.4 & 5.1 & & & & \\
\hline Ex-Yugoslavs & 11.8 & 10.6 & & & & \\
\hline Southern Europeans & 23.4 & 26.3 & & & & \\
\hline Eastern Europeans & 10.0 & 24.7 & & & & \\
\hline Others & 6.5 & 33.3 & & & & \\
\hline Education (\%) & & & $* * *$ & & & $* *$ \\
\hline Low & 65.6 & 38.2 & & 28.9 & 34.1 & \\
\hline Medium & 26.0 & 37.1 & & 47.9 & 42.2 & \\
\hline High & 8.4 & 24.7 & & 23.2 & 23.8 & \\
\hline Employment status (\%) & & & $* * *$ & & & \\
\hline Full-time & 57.2 & 56.8 & & 62.7 & 63.6 & \\
\hline Part-time & 3.7 & 8.5 & & 8.5 & 7.2 & \\
\hline Unemployed & 11.6 & 13.5 & & 9.9 & 10.1 & \\
\hline Not employed & 27.6 & 21.2 & & 18.9 & 19.1 & \\
\hline Previously married (\%) & 6.0 & 13.1 & $* * *$ & 11.5 & 12.4 & \\
\hline $\begin{array}{l}\text { Age (range 18-93) }[M \\
(S D)]\end{array}$ & $29.79(10.58)$ & $33.91(9.45)$ & $* * *$ & $35.31(10.88)$ & $35.70(10.70)$ & \\
\hline $\begin{array}{l}\text { Number of children in } \\
\text { household (range } 0-8) \\
{[M(S D)]}\end{array}$ & $0.82(1.13)$ & $0.75(0.91)$ & $\dagger$ & $0.71(0.89)$ & $0.75(0.91)$ & \\
\hline $\begin{array}{l}\text { Household income, } \ln \\
\text { (range 6.87-14.22) }[M \\
(S D)]\end{array}$ & $9.98(0.55)$ & $10.35(0.57)$ & $* * *$ & $10.35(0.50)$ & $10.38(0.56)$ & \\
\hline$N$ (observations) & 9,470 & 4,331 & & 49,816 & 4,059 & \\
\hline$N$ (individuals) & 1,012 & 521 & & 5,433 & 507 & \\
\hline
\end{tabular}

Note: For respondents who experienced the transition into a union, figures related to time-varying variables correspond to values measured at reaction (i.e., the first two years after union formation)

Significance values for union type differences: $\dagger p<.10,{ }^{*} p<0.05 ; * * p<0.01 ; * * *<0.001$

baseline level of life satisfaction than those partnering someone of the same origin. First generation men who match with native women therefore have a significant life satisfaction advantage at set-point, regardless of socio-demographic profile, confirming hypothesis 1.1. For natives, additional models including a gender interaction (not reported) showed that irrespective of gender, union type is not linked to different baseline levels of SWB. 


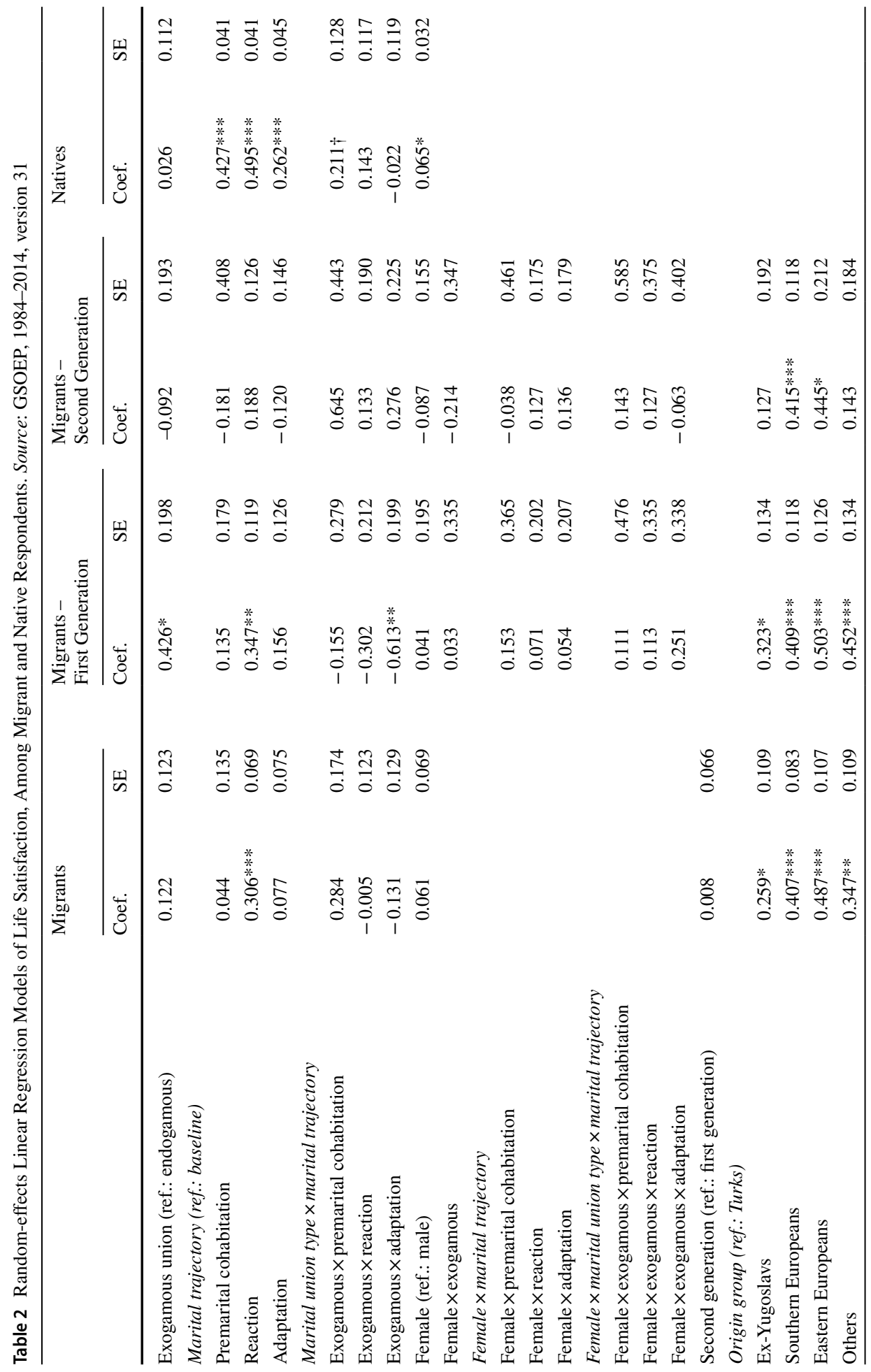




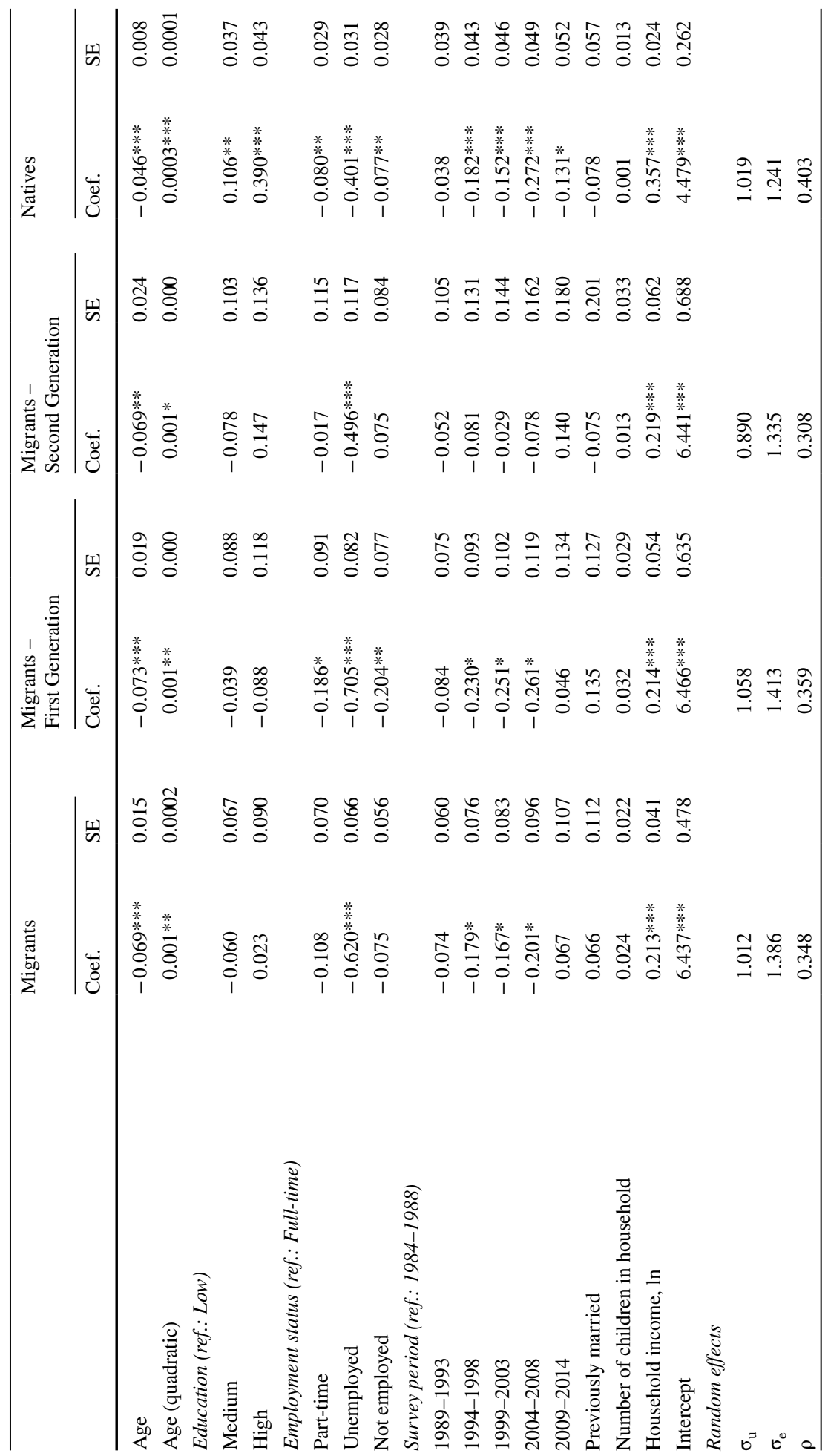




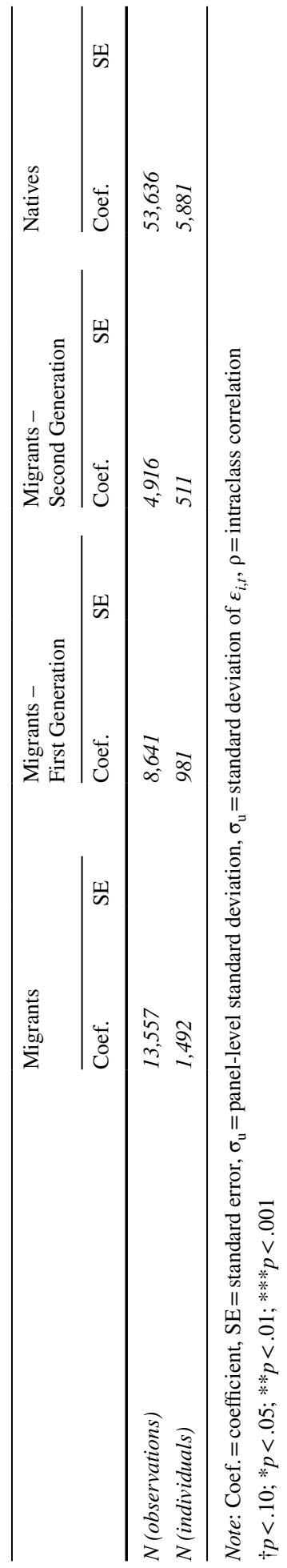




\subsection{Results of Distributed Fixed-effects Models}

Furthermore, we proposed that in the reaction phase, mixed unions would improve SWB to a greater extent than matching endogamously (hypothesis 2 ). It was also claimed that the greater gains in life satisfaction for exogamous versus endogamous couples would be more evident in the reaction than in the premarital cohabitation phase (hypothesis 3 ). To test these assumptions, we look at the change in life satisfaction (compared to baseline) observed during premarital cohabitation, and then reaction, in distributed fixed-effects models. To visually grasp the magnitude of results, we plotted regression estimates in Fig. 1. The stage-by-stage differences in life satisfaction for each union type, as well as the exogamy SWB premium (i.e., the contrast between exogamy and endogamy) are additionally reported in Table 3 for migrants, and Table 4 for natives (Total Sample panels).

First, we see that there is a life satisfaction premium when partnering exogamously (versus endogamously) in the premarital cohabitation phase for both migrants (0.237) and natives (0.179), but the contrast is not statistically significant for either group. There is also a mixed marriage premium, though much smaller and again non-significant, in the reaction phase for both migrants (0.022) and natives (0.104). Hypothesis 2 therefore does not receive empirical support. The data also refute hypothesis 3 given that for both groups, the mixed union premium is in fact larger in the cohabiting phase than in the first two years post-marriage.

We also proposed that the intermarriage premium in SWB during the two reaction stages would be stronger for migrants than natives, especially among women (hypothesis 4). Results reported in Tables 3 and 4 (Male Sample and Female Sample panels) partially confirm this expectation for migrant women in the pre-marital cohabitation phase. Before marrying, migrant women co-residing with a German man experience an exogamy premium of 0.357 points, whereas native women cohabiting with an migrant man experience an exogamy premium of 0.178 points only. Nevertheless, shortly after marriage, it is native women that experience a greater exogamy premium ( 0.291 compared to 0.122 for migrant women). None of the premium values are however statistically significant. When it comes to men and their change in life satisfaction in the pre-marital cohabitation stage, we notice that both migrant and native men experience an added benefit from partnering exogamously, but, contrary to expectations, the magnitude of the premium, albeit non-significant in both cases, is greater for native ( 0.221$)$ than migrant men $(0.146)$. In the reaction phase, both migrant and native men experience a greater gain when having a same-origin than a different-origin partner, but the endogamy premiums ( 0.049 , and 0.060 respectively) are small and non-significant.

We additionally suggested that having a different- rather than same-origin partner is linked to a larger short-term drop in SWB from reaction to adaptation (hypothesis 5), and a negative effect of intermarriage on life satisfaction in the long run, i.e., from baseline to adaptation (hypothesis 6). Results in Table 3 (Total Sample panel) show that for migrants, the short-term drop in life satisfaction has a greater magnitude in exogamous $(-0.342)$ than in endogamous unions $(-0.217)$, but the difference between the two types of union (contrast value -0.125 ) is insignificant. For natives, findings reported in Table 4 (Total Sample panel) indicate that exogamous couples experience a much larger and statistically significant short-term decrease in SWB than endogamous couples (contrast value -0.166). Hypothesis 5 therefore receives empirical support for natives. We additionally notice that for exogamous natives, life satisfaction does not drop significantly lower than its level at baseline, nor the level experienced by endogamous natives during the same period (Fig. 1, Panel B). 

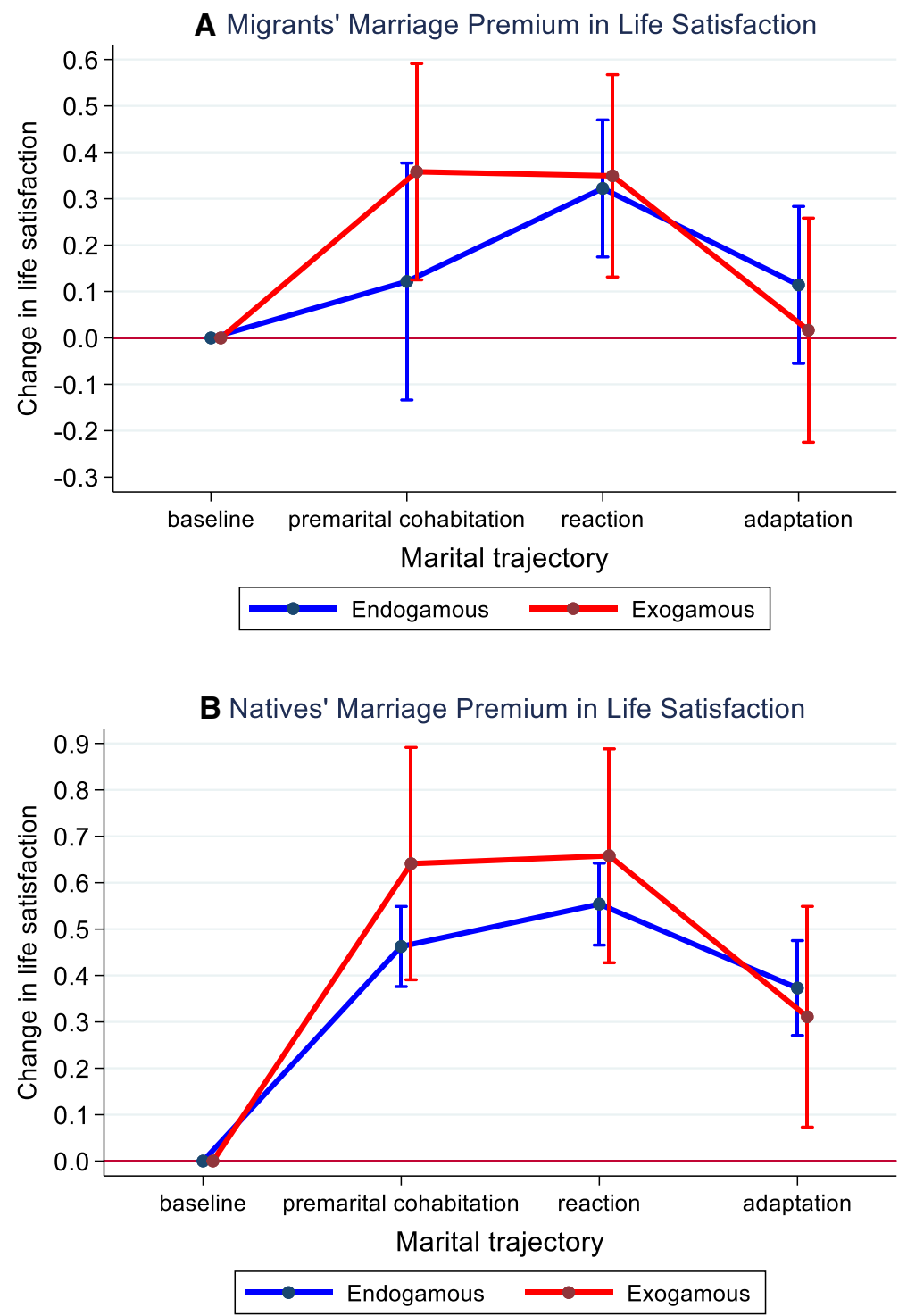

Fig. 1 Life satisfaction trajectories of migrants (a) and natives (b) before and after union formation, by union type (95\% confidence interval, panel-robust standard errors). Notes: Based on two distributed fixedeffects linear regression models of life satisfaction with an interaction between union type and union trajectory, controlling for household income (ln), employment status, age (linear and quadratic), survey period, whether previously married, and number of children in household

For migrants in both endogamous and exogamous couples, SWB decreases to a level that renders it statistically indistinguishable from baseline. The assumptions of set-point theory are therefore valid for migrants (irrespective of union type), and invalid for natives, who manage to sustain a long-term gain in SWB in both endogamous and exogamous marriages. 
Table 3 Stage-by-stage Differences in the Predicted Means of Migrants' Life Satisfaction, by Union Type

\begin{tabular}{lccc}
\hline & Endogamy & Exogamy & $\begin{array}{l}\text { Exogamy versus } \\
\text { Endogamy Contrast }\end{array}$ \\
\hline Total sample & & & \\
Premarital cohabitation versus baseline & 0.123 & $0.360^{* *}$ & 0.237 \\
Reaction versus baseline & $0.321^{* * *}$ & $0.344^{* *}$ & 0.022 \\
Adaptation versus reaction & $-0.217^{* * *}$ & $-0.342^{* * *}$ & -0.125 \\
Adaptation versus baseline & 0.104 & 0.002 & -0.103 \\
Male sample & & & \\
Premarital cohabitation versus baseline & 0.141 & $0.287^{*}$ & 0.146 \\
Reaction versus baseline & $0.312^{* *}$ & $0.263^{*}$ & -0.049 \\
Adaptation versus reaction & $-0.204^{* *}$ & $-0.313^{* * *}$ & -0.109 \\
Adaptation versus baseline & 0.108 & -0.050 & -0.158 \\
Female sample & & & 0.357 \\
Premarital cohabitation versus baseline & 0.109 & $0.466^{*}$ & 0.122 \\
Reaction versus baseline & $0.338^{* *}$ & $0.460^{*}$ & -0.143 \\
Adaptation versus reaction & $-0.227^{* *}$ & $-0.371^{* * *}$ & -0.022 \\
Adaptation versus baseline & 0.111 & 0.089 &
\end{tabular}

Note: $* p<.05 ; * * p<.01 ; * * * p<.001$

Table 4 Stage-by-stage Differences in the Predicted Means of Natives' Life Satisfaction, by Union Type

\begin{tabular}{lrcc}
\hline & Endogamy & Exogamy & $\begin{array}{l}\text { Exogamy versus } \\
\text { Endogamy Contrast }\end{array}$ \\
\hline Total sample & & & \\
Premarital cohabitation versus baseline & $0.462^{* * *}$ & $0.641^{* * *}$ & 0.179 \\
Reaction versus baseline & $0.554^{* * *}$ & $0.658^{* * *}$ & 0.104 \\
Adaptation versus reaction & $-0.181^{* * *}$ & $-0.347^{* * *}$ & $-0.166^{* *}$ \\
Adaptation versus baseline & $0.373^{* * *}$ & $0.311^{*}$ & -0.062 \\
Male sample & & & \\
Premarital cohabitation versus baseline & $0.523^{* * *}$ & $0.744^{* * *}$ & 0.221 \\
Reaction versus baseline & $0.591^{* * *}$ & $0.531^{* * *}$ & -0.060 \\
Adaptation versus reaction & $-0.187^{* * *}$ & $-0.312^{* * *}$ & -0.125 \\
Adaptation versus baseline & $0.404^{* * *}$ & 0.219 & -0.185 \\
Female sample & & & \\
Premarital cohabitation versus baseline & $0.396^{* * *}$ & $0.574^{* *}$ & 0.178 \\
Reaction versus baseline & $0.508^{* * *}$ & $0.799^{* * *}$ & 0.291 \\
Adaptation versus reaction & $-0.178^{* * *}$ & $-0.392^{* * *}$ & $-0.214^{*}$ \\
Adaptation versus baseline & $0.330^{* * *}$ & $0.407 \dagger$ & 0.077 \\
\hline
\end{tabular}

Note: $\dagger p<.10 ; * p<.05 ; * * p<.01 ; * * * p<.001$

Hypothesis 6 suggesting that mixed marriage produces a significant long-term hindering effect on individuals' life satisfaction (compared to baseline) is refuted.

Finally, we anticipated that during adaptation, there might be a sharper decrease in SWB (compared to both reaction and baseline) for inter-married women than inter-married men (hypothesis 7), particularly for German women married to migrant men (hypothesis 
7.1). The estimates in Table 3 indicate that for both migrant men and migrant women in exogamous couples, there is no significant extra drop in life satisfaction in either the short or the long run. Hypothesis 7 is thus not confirmed for migrant women. Table 4 however shows that native women married to migrant men do experience a significantly greater SWB decrease (contrast value -0.214) moving from an earlier (i.e., reaction) to a later stage (i.e., adaptation) in marriage compared to native women partnered with native men. Native men also experience an extra drop in SWB when marrying exogamously, but it is smaller and non-significant (contrast value - 0.125). When looking at the long-term evolution of SWB throughout the broader marital trajectory, results show that, contrary to expectations, native women with a migrant spouse have a significant (at $p<.10)$ and large long-term increase (compared to baseline) in life satisfaction (0.407), one that surpasses the long-term increase for intermarried native men (0.219), as well as that witnessed by native women in endogamous unions (0.330). The premium (i.e., the exogamy-endogamy contrast of 0.077 ) is however narrow and non-significant. The expectation of life satisfaction dropping for native women married to migrant men is hence only confirmed when focusing on the short-term decrease from the reaction phase to the more established years after marriage, but not when taking pre-partnering SWB levels as reference.

We also conducted several auxiliary analyses meant to confirm the robustness of our findings for different sub-groups (e.g., respondents without previous marital experience, specific migrant groups, educationally homogamous couples, etc.). Results are reported and commented on in the Supplementary Material.

\section{Discussion}

This study set out to understand how entering a mixed marriage affects migrants and natives' SWB over time. To date, research on the long-term consequences of mixed unions mostly explored immigrants' economic-related advantages of partnering natives (e.g., Elwert and Tegunimataka 2016; Nystedt and Dribe 2015). We expand the literature by focusing on the outcome of SWB, a key factor known to have altering effects on health and all-cause mortality (Diener and Chan 2011). Given the mounting immigration flows throughout most Western countries in recent years, the constant replenishment of immigrant populations, and the current rise in mixed unions (Lanzieri 2012), establishing how exogamous unions influence trajectories of SWB is highly warranted. Using panel data from the German Socio-Economic Panel, we examined changes in life satisfaction before and after the transition to an exogamous (versus endogamous) union. A key strength of these data is that they allowed us to test the link between inter-partnering and SWB with a dynamic lens instead of the static association explored by previous studies using cross-sectional information (e.g., Fu et al. 2001). Drawing from set-point theory (Suh et al. 1996), the study distinguished between selection, short-term (i.e., premarital cohabitation, reaction) and longerterm (i.e., adaptation) effects. To gain a broad perspective on this issue, we investigated how inter-partnering affects SWB for both migrants and natives, and by gender. Finally, by means of random-effects modeling, we examined between-subject variation in life satisfaction levels before partnering (i.e., selection); through distributed fixed-effects modeling, we then accounted for phase-specific unobserved heterogeneity, and were able to tease out the short- and long-term evolution of life satisfaction after union formation. An overview of hypotheses and results is provided in Table 5. 


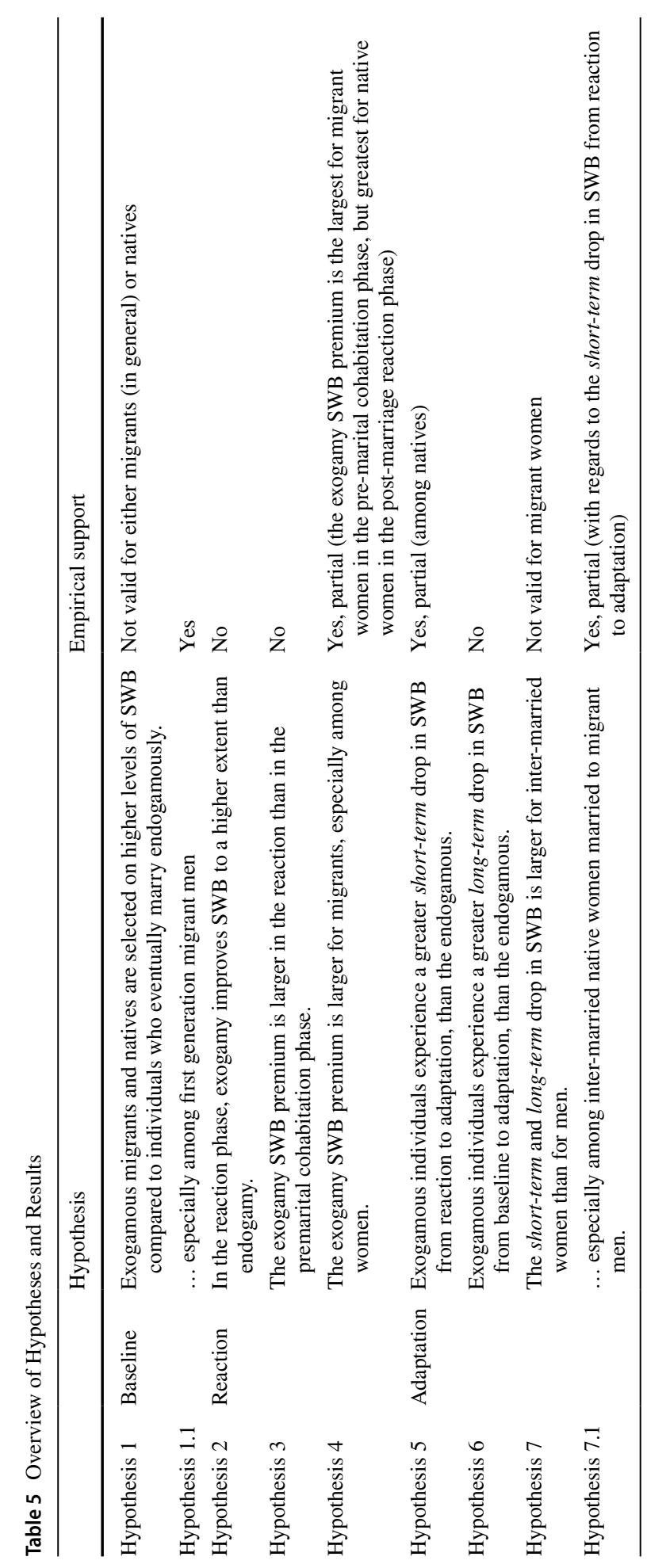


Our analyses first showed that first generation immigrant men who (eventually) marry German women have already higher pre-union levels of life satisfaction than those endogamously matched. The intermarriage selection on SWB (for this sub-group) is in line with previous research showing that exogamous migrant men in Sweden, particularly those from the first generation, display positive labor market outcomes prior to marrying a native (Nystedt and Dribe 2015). Our study suggests that it is not only high levels of economic and human capital that boost first generation migrant men's chances of marrying a native woman, but also their elevated mental health capital. The fact that it was only first generation migrant men who appeared to be selective on SWB may also indicate a position of greater vulnerability (compared to second generation migrants or migrant women in general) in the marriage market, which high SWB may compensate for.

The inclusion of the premarital cohabiting stage in the marital trajectory allowed us to account for the complex sequencing of mixed partnering histories (Kulu and GonzálezFerrer 2014). Findings revealed that all groups, but especially migrant women, experience a life satisfaction premium, albeit non-significant, when cohabiting before intermarriage than when cohabiting prior to endogamously marrying. For certain groups (e.g., migrant and native men), we noticed in fact an exogamy SWB premium during pre-marital cohabitation but not during reaction, i.e., the first two years of marriage. The added benefit of exogamy versus endogamy being witnessed in the premarital cohabitation stage is suggestive of the normative legitimacy of cohabiting before marrying in the German context (Kasearu and Kutsar 2011), and the "honeymoon" effect possibly occurring pre-marriage rather than post-marriage. The fact that compared to men in endogamous unions, those in exogamous couples did not experience supplementary gains in life satisfaction in the first two years of marriage may indicate that for men, the benefits of marrying are universal, irrespective of partner's origin. For first generation migrant men, already high pre-partnering levels of SWB may also minimize any marginal effect of marriage.

Furthermore, native women represent the only group for whom having an exogamous partner largely increases SWB when transitioning to marriage and shortly after (i.e., the reaction phase) more than having an endogamous partner, though the contrast is insignificant. Native women experiencing a substantive short-term intermarriage premium is especially the case when the migrant spouse is a first generation migrant man (e.g., in the Supplementary File see Figure S4.3 based on analyses distinguishing between the first- versus second generation migrant partners). As women are generally better at coping with individual or cultural differences than men (Miville et al. 1999), one possible explanation is that native women marrying an immigrant man adapt easier and benefit more from blending two cultural backgrounds than native men marrying migrant women. A closer look at the educational sorting of mixed couples (numbers not shown) also revealed that intermarried native women (especially those with a medium-level education) are more often partnering down on education than migrant women in endogamous unions. Given a surplus of native women with medium-level education (see descriptive figures in Table S02 in the Supplementary File), the exogamy SWB gain is likely related to finding a partner, albeit lower educated, and marrying in an otherwise tense marriage market.

Migrant women experiencing a smaller intermarriage premium than native women could also be related to migrant status-based stress, but also the asymmetrical power relations that describe bi-national marriages between migrant wives and native husbands, the former more often legally and economically dependent on the latter (Dribe and Lundh 2011; Riaño 2011). Any advantage derived from marrying a native and any subsequent increase in life satisfaction might therefore be offset by unequal spousal dynamics (Pong et al. 2014). While we accounted for socio-economic characteristics, future research should 
look closer at couple-level composition and the distribution of roles within the (inter) marriage.

We finally noticed that in the long-term, irrespective of the origin of their partner, migrants return to their pre-partnering level of SWB, thus confirming set-point theory, whereas natives maintain a long-term SWB increase. For natives, marriage sustains a high level of life satisfaction even when the early effects of marrying fade off. Having relatively fewer socio-demographic resources, and the challenges related to the experience of integration likely tone down the positive effects of marital transitions on migrants' life satisfaction.

The finding that across all groups, the SWB level of the exogamously married does not descend to a significantly lower level than that of the endogamously matched in the adaptation phase indicates that in the long run, the origin of the partner has little consequence on life satisfaction. Contrary to previous studies that almost consistently encountered the interpartnered as worse off in terms of mental and emotional health (e.g., Bratter and Eschbach 2006; Kroeger and Williams 2011) or other research that identified a negative effect for majority group members only (Milewski and Gawron 2019), we showed that mixed unions are not more detrimental to SWB than unions involving endogamous partners. On the contrary, the data reveal that exogamy bestows some benefits in terms of life satisfaction, though short-lived (displayed when either cohabiting before marriage or in the first two years of marriage) and insignificant. Exogamy between a native and a migrant partner therefore does not yield a substantive short-term SWB premium, but more importantly, it does not impose significant long-term costs. In an era marked by increasing diversity, and as mixed unions become more commonplace (Lanzieri 2012), finding similar long-term SWB returns to marrying a different- versus a same-origin partner is an important empirical observation. A first reason behind this finding, which goes against previous knowledge, is that past research mainly relied on cross-sectional information and was unable to take a dynamic perspective that could examine the process of inter-partnering both within and across individuals. A second and related point is that previous scholarship did not account for selection into mixed unions or the role of unobserved characteristics. Controlling for unobserved heterogeneity allowed us to reveal that having a different-origin partner does not induce more long-term vulnerability (i.e., a decrease in SWB) than choosing a sameorigin partner. Finally, another reason why our findings diverge from previous work focusing on inter-racial mixing in the U.S. might be the different nature of conjugal mixing between non-immigrants and immigrants in Europe versus in a context with long established and still rigid racial hierarchies (Drouhot and Nee 2019).

This study also leaves open questions that should be addressed in future research. Our data made it difficult to assess and compare trajectories of SWB for specific immigrant groups. We invite future studies using larger migrant samples to directly test whether contrasts in the intermarriage SWB premium across different groups depend on specific aspects of socio-economic integration, or derive from pre-migration "cultures of life satisfaction" (Voicu and Vasile 2014). The role played by educational matching in the life satisfaction of exogamous partners also deserves further consideration. Furthermore, future work could engage in detailed analyses of domain-specific well-being or relationship satisfaction instead of overall life satisfaction; similarly, future research could look at couple dynamics and ways in which men and women of different origin negotiate partner roles (e.g., the allocation of household labour) depending on each other's employment performance or country-of-origin gender norms' regime. Moreover, for some immigrant groups from Turkey and former Yugoslavia, a distinction between imported versus co-resident partners within endogamous unions (Eeckhaut et al. 2011; González-Ferrer 2005), with large enough samples, is also required. Finally, research could address the role of national 
context (e.g., Hendriks and Bartram 2016), and social attitudes towards inter-partnering on migrants' SWB. Societal disapproval of mixed unions likely provides additional stressors and affects how such partnerships are experienced and evolve in the long run (Kroeger and Williams 2011).

Acknowledgements This paper benefited from the support of the Swiss National Centre of Competence in Research LIVES - Overcoming vulnerability: Life course perspectives, which is financed by the Swiss National Science Foundation (grant number: 51NF40-160590).

\section{References}

Alba, R., \& Nee, V. (2005). Remaking the American mainstream: Assimilation and contemporary immigration (F First Paperback Edition Used edition.). Cambridge, MA: Harvard University Press.

Algan, Y., Dustmann, C., Glitz, A., \& Manning, A. (2010). The economic situation of first and second-generation immigrants in France, Germany and the United Kingdom. The Economic Journal, 120(542), F4-F30. https://doi.org/10.1111/j.1468-0297.2009.02338.x.

Allison, P. D. (2009). Fixed effects regression models (1st ed.). Los Angeles: SAGE Publications Inc.

Amit, K., \& Bar-Lev, S. (2015). Immigrants' sense of belonging to the host country: The role of life satisfaction, language proficiency, and religious motives. Social Indicators Research, 124(3), 947-961. https://doi.org/10.1007/s11205-014-0823-3.

Angelini, V., Casi, L., \& Corazzini, L. (2015). Life satisfaction of immigrants: Does cultural assimilation matter? Journal of Population Economics, 28(3), 817-844. https://doi.org/10.1007/s00148-015-0552-1.

Anusic, I., Yap, S. C. Y., \& Lucas, R. E. (2014). Testing set-point theory in a Swiss national sample: Reaction and adaptation to major life events. Social Indicators Research, 119(3), 1265-1288. https://doi. org/10.1007/s11205-013-0541-2.

Baker, M., \& Benjamin, D. (1997). The role of the family in immigrants' labor-market activity: An evaluation of alternative explanations. American Economic Review, 87(4), 705-727.

Barr, A. B., \& Simons, R. L. (2014). A dyadic analysis of relationships and health: Does couple-level context condition partner effects? Journal of Family Psychology, 28(4), 448-459. https://doi.org/10.1037/ a0037310.

Bauer, G. (2014). Graphical display of regression results. In H. Best \& C. Wolf (Eds.), The SAGE handbook of regression analysis and causal inference (pp. 205-224). London: SAGE Publications Ltd. https:// doi.org/10.4135/9781446288146.

Behtoui, A. (2010). Marriage pattern of immigrants in Sweden. Journal of Comparative Family Studies, 41(3), 415-435.

Bratter, J. L., \& Eschbach, K. (2006). 'What about the couple?' Interracial marriage and psychological distress. Social Science Research, 35(4), 1025-1047. https://doi.org/10.1016/j.ssresearch.2005.09.001.

Bratter, J. L., \& King, R. B. (2008). "But will it last?”: Marital instability among interracial and same-race couples. Family Relations, 57(2), 160-171. https://doi.org/10.1111/j.1741-3729.2008.00491.x.

Brüderl, J., \& Ludwig, V. (2015). Fixed-effects panel regression. In The SAGE handbook of regression analysis and causal inference (pp. 327-358). London: SAGE Publications Ltd. https://doi. org/10.4135/9781446288146

Carol, S. (2016). Like will to like? Partner choice among muslim migrants and natives in Western Europe. Journal of Ethnic and Migration Studies, 42(2), 261-276. https://doi.org/10.1080/13691 83 X.2014.963037.

Çelik, Ç. (2015). 'Having a German passport will not make me German': Reactive ethnicity and oppositional identity among disadvantaged male Turkish second-generation youth in Germany. Ethnic and Racial Studies, 38(9), 1646-1662. https://doi.org/10.1080/01419870.2015.1018298.

Clark, A. E., \& Georgellis, Y. (2013). Back to baseline in Britain: Adaptation in the british household panel survey. Economica, 80(319), 496-512. https://doi.org/10.1111/ecca.12007.

Collet, B. (2015). From intermarriage to conjugal mixedness: Theoretical considerations illustrated by empirical data in France. The ANNALS of the American Academy of Political and Social Science, 662(1), 129-147. https://doi.org/10.1177/0002716215595388.

Cummins, R. A., Li, N., Wooden, M., \& Stokes, M. (2014). A demonstration of set-points for subjective wellbeing. Journal of Happiness Studies, 15(1), 183-206. https://doi.org/10.1007/s1090 2-013-9444-9. 
Cyrus, N., \& Vogel, D. (2005). Germany. In J. Niessen (Ed.), Current immigration debates in Europe: A publication of the European migration dialogue (pp. 1-35). Brussels: Migration Policy Group.

de Valk, H. A. G., \& Medrano, J. D. (2014). Guest editorial on meeting and mating across borders: Union formation in the European union single market. Population, Space and Place, 20(2), 103109. https://doi.org/10.1002/psp.1768.

Diener, E., \& Chan, M. Y. (2011). Happy people live longer: Subjective well-being contributes to health and longevity. Applied Psychology: Health and Well-Being, 3(1), 1-43. https://doi.org/10.111 1/j.1758-0854.2010.01045.x.

Diener, E., Lucas, R. E., \& Scollon, C. N. (2006). Beyond the hedonic treadmill: Revising the adaptation theory of well-being. American Psychologist, 61(4), 305. https://doi. org/10.1037/0003-066X.61.4.305.

Diener, E., \& Seligman, M. E. P. (2002). Very happy people. Psychological Science, 13(1), 81-84. https ://doi.org/10.1111/1467-9280.00415.

Donato, K. M., Alexander, J. T., Gabaccia, D. R., \& Leinonen, J. (2011). Variations in the gender composition of immigrant populations: How they matter. International Migration Review, 45(3), 495526. https://doi.org/10.1111/j.1747-7379.2011.00856.x.

Dougherty, C. (2006). The marriage earnings premium as a distributed fixed effect. The Journal of Human Resources, 41(2), 433-443.

Dribe, M., \& Lundh, C. (2008). Intermarriage and immigrant integration in Sweden: An exploratory analysis. Acta Sociologica, 51(4), 329-354. https://doi.org/10.1177/0001699308097377.

Dribe, M., \& Lundh, C. (2011). Cultural dissimilarity and intermarriage. A longitudinal study of immigrants in Sweden 1990-20051. International Migration Review, 45(2), 297-324. https://doi.org/10 .1111/j.1747-7379.2011.00849.x.

Drouhot, L. G., \& Nee, V. (2019). Assimilation and the second generation in Europe and America: Blending and segregating social dynamics between immigrants and natives. Annual Review of Sociology, 45(1), 177-199. https://doi.org/10.1146/annurev-soc-073117-041335.

Eeckhaut, M. C. W., Lievens, J., Van de Putte, B., \& Lusyne, P. (2011). Partner selection and divorce in ethnic minorities: Distinguishing between two types of ethnic homogamous marriages. International Migration Review, 45(2), 269-296. https://doi.org/10.1111/j.1747-7379.2011.00848.x.

Eid, M., \& Diener, E. (2004). Global judgments of subjective well-being: Situational variability and long-term stability. Social Indicators Research, 65(3), 245-277. https://doi.org/10.1023/ B:SOCI.0000003801.89195.bc.

Elgorriaga Astondoa, E., Arnoso Martínez, A., \& Ibabe Erostarbe, I. (2020). Condiciones sociolaborales e integración social de mujeres y hombres españoles en Alemania e Inglaterra/Socio-Labour Conditions and Social Integration of Spanish Women and Men in Germany and England. Revista Española de Investigaciones Sociológicas. https://doi.org/10.5477/cis/reis.170.55.

Elwert, A., \& Tegunimataka, A. (2016). Cohabitation premiums in Denmark: Income effects in immigrant-native partnerships. European Sociological Review, 32(3), 383-402. https://doi.org/10.1093/ esr/jcw018.

Fu, V. K. (2001). Racial intermarriage pairings. Demography, 38(2), 147-159. https://doi.org/10.1353/ dem.2001.0011.

Fu, X., Tora, J., \& Kendall, H. (2001). Marital happiness and inter-racial marriage: A study in a multiethnic community in Hawaii. Journal of Comparative Family Studies, 32(1), 47.

Galli, F., \& Russo, G. (2019). Immigration restrictions and second-generation cultural assimilation: Theory and quasi-experimental evidence. Journal of Population Economics, 32(1), 23-51. https://doi. org/10.1007/s00148-018-0694-z.

Gerhards, J., \& Buchmayr, F. (2018). Unterschiede zwischen der ersten und zweiten Generation von Migrantinnen in der Wahrnehmung symbolischer Grenzen und in den Strategien ihrer Grenzarbeit. Berliner Journal für Soziologie, 28(3), 367-395. https://doi.org/10.1007/s11609-018-0376-4.

González-Ferrer, A. (2005). Who do immigrants marry? Partner choice among single immigrants in Germany. European Sociological Review, 22(2), 171-185. https://doi.org/10.1093/esr/jci050.

Gordon, M. M. (1964). Assimilation in American life: The role of race, religion and national origins (1st ed.). New York, N.Y: Oxford University Press.

Grigoleit-Richter, G. (2017). Highly skilled and highly mobile? Examining gendered and ethnicised labour market conditions for migrant women in STEM-professions in Germany. Journal of Ethnic and Migration Studies, 43(16), 2738-2755. https://doi.org/10.1080/1369183X.2017.1314597.

Grover, S., \& Helliwell, J. F. (2019). How's life at home? New evidence on marriage and the set point for happiness. Journal of Happiness Studies, 20(2), 373-390. https://doi.org/10.1007/s10902-017-9941-3.

Guven, C. (2011). Are happier people better citizens? Kyklos, 64(2), 178-192. https://doi.org/10.111 1/j.1467-6435.2011.00501.x. 
Ha, S.-K., SeongWoo, L., Ran, S. H., \& Myers, D. (2002). Interracial marriage and residential well being: Consequences of interracial marriage for Korean women in the US. Asian Journal of Women's Studies, 8(3), 55-85.

Hannemann, T., Kulu, H., Rahnu, L., Puur, A., Hărăguş, M., Obućina, O., et al. (2018). Co-ethnic marriage versus intermarriage among immigrants and their descendants: A comparison across seven European countries using event-history analysis. Demographic Research, 39, 487-524. https://doi. org/10.4054/DemRes.2018.39.17.

Heidemeier, H., \& Göritz, A. S. (2016). The instrumental role of personality traits: Using mixture structural equation modeling to investigate individual differences in the relationships between the big five traits and life satisfaction. Journal of Happiness Studies, 17(6), 2595-2612. https://doi. org/10.1007/s10902-015-9708-7.

Heizmann, B., \& Böhnke, P. (2018). Immigrant life satisfaction in Europe: The role of social and symbolic boundaries. Journal of Ethnic and Migration Studies. https://doi.org/10.1080/13691 83X.2018.1438252.

Hendriks, M., \& Bartram, D. (2016). Macro-conditions and immigrants' happiness: Is moving to a wealthy country all that matters? Social Science Research, 56, 90-107. https://doi.org/10.1016/j. ssresearch.2015.11.006.

Hohmann-Marriott, B. E., \& Amato, P. (2008). Relationship quality in interethnic marriages and cohabitations. Social Forces, 87(2), 825-855. https://doi.org/10.1353/sof.0.0151.

Horwitz, A. V., White, H. R., \& Howell-White, S. (1996). Becoming married and mental health: a longitudinal study of a cohort of young adults. Journal of Marriage and Family, 58(4), 895-907. https ://doi.org/10.2307/353978.

Kalmijn, M. (1993). Trends in black/white intermarriage. Social Forces, 72(1), 119-146. https://doi. org/10.1093/sf/72.1.119.

Kalmijn, M. (2010). Consequences of racial intermarriage for children's social integration. Sociological Perspectives, 53(2), 271-286. https://doi.org/10.1525/sop.2010.53.2.271.

Kalmijn, M., \& van Tubergen, F. (2007). Ethnic intermarriage in the Netherlands: Confirmations and refutations of accepted insights. European Journal of Population/Revue européenne de Démographie, 22(4), 371-397. https://doi.org/10.1007/s10680-006-9105-3.

Kasearu, K., \& Kutsar, D. (2011). Patterns behind unmarried cohabitation trends in Europe. European Societies, 13(2), 307-325. https://doi.org/10.1080/14616696.2010.493586.

Killian, K. D. (2001). Reconstituting racial histories and identities: The narratives of interracial couples. Journal of Marital and Family Therapy, 27(1), 27-42. https://doi.org/10.1111/j.1752-0606.2001. tb01137.x.

Kim, H. K., \& McKenry, P. C. (2002). The relationship between marriage and psychological well-being a longitudinal analysis. Journal of Family Issues, 23(8), 885-911. https://doi.org/10.1177/01925 1302237296.

Klärner, A., \& Knabe, A. (2017). On the normative foundations of marriage and cohabitation: Results from group discussions in eastern and western Germany. Demographic Research, 36, 1637-1666. https://doi.org/10.4054/DemRes.2017.36.53.

Koelet, S., \& de Valk, H. A. (2016). Social networks and feelings of social loneliness after migration: The case of European migrants with a native partner in Belgium. Ethnicities, 16(4), 610-630. https://doi.org/10.1177/1468796816638398.

Kroeger, R. A., \& Williams, K. (2011). Consequences of black exceptionalism? Interracial unions with blacks, depressive symptoms, and relationship satisfaction. The Sociological Quarterly, 52(3), 400-420. https://doi.org/10.1111/j.1533-8525.2011.01212.x.

Kulu, H., \& González-Ferrer, A. (2014). Family dynamics among immigrants and their descendants in Europe: Current research and opportunities. European Journal of Population, 30(4), 411-435. https://doi.org/10.1007/s10680-014-9322-0.

Lanzieri, G. (2012). Mixed marriages in Europe 1990-2010. In Cross-border marriage: Global trends and diversity (pp. 81-122). Seoul: Korea Institute for Health and Social Affairs. http://www.researchgate.net/ profile/Giampaolo_Lanzieri/publication/258210005_Mixed_Marriages_in_Europe_1990-2010/links /02e7e5273dffb13523000000.pdf. Accessed 22 June 2015

LeBlanc, A. J., Frost, D. M., \& Wight, R. G. (2015). Minority stress and stress proliferation among same-sex and other marginalized couples. Journal of Marriage and Family, 77(1), 40-59. https://doi.org/10.1111/ jomf.12160.

Lipps, O. (2009). Attrition of households and individuals in panel surveys (No. 164). DIW Berlin, The German Socio-Economic Panel (SOEP). https://ideas.repec.org/p/diw/diwsop/diw_sp164.html. Accessed 15 January 2020 
Lucas, R. E., Clark, A. E., Georgellis, Y., \& Diener, E. (2003). Reexamining adaptation and the set point model of happiness: Reactions to changes in marital status. Journal of Personality and Social Psychology, 84(3), 527. https://doi.org/10.1037/0022-3514.84.3.527.

Luhmann, M., Hofmann, W., Eid, M., \& Lucas, R. E. (2012). Subjective well-being and adaptation to life events: A meta-analysis. Journal of Personality and Social Psychology, 102(3), 592-615. https://doi. org/10.1037/a0025948.

Luthra, R. R. (2013). Explaining ethnic inequality in the German labor market: Labor market institutions, context of reception, and boundaries. European Sociological Review, 29(5), 1095-1107. https://doi. org/10.1093/esr/jcs081.

Lykken, D., \& Tellegen, A. (1996). Happiness is a stochastic phenomenon. Psychological Science, 7(3), 186189. https://doi.org/10.1111/j.1467-9280.1996.tb00355.x.

Martin, B. A., Cui, M., Ueno, K., \& Fincham, F. D. (2013). Intimate partner violence in interracial and monoracial couples. Family Relations, 62(1), 202-211. https://doi.org/10.1111/j.1741-3729.2012.00747.x.

Massey, D. S., \& Akresh, I. R. (2006). Immigrant intentions and mobility in a global economy: The attitudes and behavior of recently arrived U.S. immigrants. Social Science Quarterly, 87(5), 954-971. https://doi. org/10.1111/j.1540-6237.2006.00410.x.

McAvay, H. (2018). How durable are ethnoracial segregation and spatial disadvantage? Intergenerational Contextual Mobility in France. Demography, 55(4), 1507-1545. https://doi.org/10.1007/s13524-018-0689-0.

McNamara, R. P., Tempenis, M., \& Walton, B. (1999). Crossing the line: Interracial couples in the South. Westport: Praeger.

Meng, X., \& Gregory, R. (2005). Intermarriage and the economic assimilation of immigrants. Journal of Labor Economics, 23(1), 135-176.

Meng, X., \& Meurs, D. (2009). Intermarriage, language, and economic assimilation process: A case study of France. International Journal of Manpower, 30(1/2), 127-144.

Milewski, N. (2007). First child of immigrant workers and their descendants in West Germany: Interrelation of events, disruption, or adaptation? Demographic Research, 17, 859-896. https://doi.org/10.4054/DemRe s.2007.17.29.

Milewski, N., \& Gawron, A. (2019). Is there an association between marital exogamy of immigrants and nonmigrants and their mental health? A two-partners approach. Demographic Research, 40, 561-598. https:// doi.org/10.4054/DemRes.2019.40.21.

Miville, M. L., Gelso, C. J., Pannu, R., Liu, W., Touradji, P., Holloway, P., et al. (1999). Appreciating similarities and valuing differences: The Miville-Guzman Universality-Diversity Scale. Journal of Counseling Psychology, 46(3), 291-307. https://doi.org/10.1037/0022-0167.46.3.291.

Mushaben, P. J. M. (2009). Up the down staircase: Redefining gender identities through migration and ethnic employment in Germany. Journal of Ethnic and Migration Studies, 35(8), 1249-1274. https://doi. org/10.1080/13691830903123062.

Myrskylä, M., \& Margolis, R. (2014). Happiness: Before and after the kids. Demography, 51(5), 1843-1866. https://doi.org/10.1007/s13524-014-0321-X.

Nystedt, P., \& Dribe, M. (2015). Is there an intermarriage premium for male immigrants? Exogamy and earnings in Sweden 1990-2009. International Migration Review, 49(1), 3-35. https://doi.org/10.1111/ imre. 12081.

OECD/EU. (2015). Indicators of immigrant integration 2015: Settling In. Paris: OECD Publishing. https://doi. org/10.1787/9789264234024-en.

Oesch, D., \& Lipps, O. (2013). Does unemployment hurt less if there is more of it around? A panel analysis of life satisfaction in Germany and Switzerland. European Sociological Review, 29(5), 955-967. https://doi. org/10.1093/esr/jcs071.

Özateşler-Ülkücan, G. (2019). Creating a 'we' between categories: Social categories and Alevi-Sunni intermarriages. Identities. https://doi.org/10.1080/1070289X.2019.1627069.

Pong, S., Post, D., Ou, D., \& Fok, M. S. Y. (2014). Blurring boundaries? Immigration and exogamous marriages in Hong Kong. Population and Development Review, 40(4), 629-652. https://doi.org/10.111 1/j.1728-4457.2014.00004.x.

Potârcă, G., \& Mills, M. (2015). Racial preferences in online dating across European countries. European Sociological Review, 2015, 1-16. https://doi.org/10.1093/esr/jcu093.

Riaño, Y. (2011). "He's the Swiss Citizen, I'm the Foreign spouse": Binational marriages and the impact of family-related migration policies on social integration and gender relations. In A. Kraler, E. Kofman, M. Kohli, \& C. Schmoll (Eds.), Gender, generations, and the family in international migration. Amsterdam: Amsterdam University Press.

Rodríguez-García, D., Solana-Solana, M., \& Lubbers, M. J. (2016). Preference and prejudice: Does intermarriage erode negative ethno-racial attitudes between groups in Spain? Ethnicities. https://doi. org/10.1177/1468796816638404. 
Safi, M. (2010a). Patterns of immigrant intermarriage in France: Intergenerational marital assimilation? Zeitschrift für Familienforschung, 20, 1.

Safi, M. (2010b). Immigrants' life satisfaction in Europe: Between assimilation and discrimination. European Sociological Review, 26(2), 159-176. https://doi.org/10.1093/esr/jcp013.

Schoeni, R. F., Stafford, F., Mcgonagle, K. A., \& Andreski, P. (2013). Response rates in national panel surveys. The ANNALS of the American Academy of Political and Social Science, 645(1), 60-87. https://doi. org/10.1177/0002716212456363.

Scott, S., \& Cartledge, K. H. (2009). Migrant assimilation in Europe: A transnational family affair. International Migration Review, 43(1), 60-89. https://doi.org/10.1111/j.1747-7379.2008.01147.x.

Seshadri, G., \& Knudson-Martin, C. (2013). How couples manage interracial and intercultural differences: Implications for clinical practice. Journal of Marital and Family Therapy, 39(1), 43-58. https://doi.org/1 0.1111/j.1752-0606.2011.00262.x.

Shamsuddin, M., \& Katsaiti, M.-S. (2019). Migration and happiness: Evidence from Germany. Journal of Happiness Studies. https://doi.org/10.1007/s10902-019-00207-6.

Singla, R., \& Holm, D. (2012). Intermarried couples, mental health and psychosocial well-being: Negotiating mixedness in the Danish context of 'homogeneity'. Counselling Psychology Quarterly, 25(2), 151-165. https://doi.org/10.1080/09515070.2012.674687.

Snijders, T., \& Bosker, R. (2011). Multilevel Analysis: An introduction to basic and advanced multilevel modeling (2nd ed.). London: SAGE Publications Ltd.

Soons, J. P. M., Liefbroer, A. C., \& Kalmijn, M. (2009). The long-term consequences of relationship formation for subjective well-being. Journal of Marriage and Family, 71(5), 1254-1270. https://doi.org/10.111 1/j.1741-3737.2009.00667.x.

Suh, E., Diener, E., \& Fujita, F. (1996). Events and subjective well-being: only recent events matter. Journal of Personality and Social Psychology, 70(5), 1091-1102.

Suldo, S. M., Minch, R., \& Hearon, B. V., (2015). Adolescent life satisfaction and personality characteristics: Investigating relationships using a five factor model. Journal of Happiness Studies, 16(4), 965-983. https ://doi.org/10.1007/s10902-014-9544-1.

Troy, A. B., Lewis-Smith, J., \& Laurenceau, J.-P. (2006). Interracial and intraracial romantic relationships: The search for differences in satisfaction, conflict, and attachment style. Journal of Social and Personal Relationships, 23(1), 65-80. https://doi.org/10.1177/0265407506060178.

Van Mol, C., \& de Valk, H. A. G. (2016). Relationship satisfaction of European binational couples in the Netherlands. International Journal of Intercultural Relations, 50, 50-59. https://doi.org/10.1016/j.ijint rel.2015.12.001.

Voicu, B., \& Vasile, M. (2014). Do ‘cultures of life satisfaction' travel? Current Sociology, 62(1), 81-99. https:// doi.org/10.1177/0011392113516651.

Wagner, G., Frick, J., \& Schupp, J. (2007). The German socio-economic panel study (SOEP): Scope, evolution and enhancements. Schmollers Jahrbuch : Journal of Applied Social Science Studies/Zeitschrift für Wirtschafts- und Sozialwissenschaften, 127(1), 139-169.

Weinberg, M. K., Heath, N., \& Tomyn, A. J. (2016). Rebound or resignation: Developing a predictive model of return to subjective wellbeing set-point. Journal of Happiness Studies, 17(4), 1565-1575. https://doi. org/10.1007/s10902-015-9659-z.

Yahirun, J. J., \& Kroeger, R. A. (2019). Parent-child relationships and interracial first union formation in the United States. Advances in Life Course Research, 42, 100307. https://doi.org/10.1016/j.alcr.2019.100307.

Zimmermann, A. C., \& Easterlin, R. A. (2006). Happily ever after? Cohabitation, marriage, divorce, and happiness in Germany. Population and Development Review, 32(3), 511-528. https://doi.org/10.111 1/j.1728-4457.2006.00135.x.

Publisher's Note Springer Nature remains neutral with regard to jurisdictional claims in published maps and institutional affiliations. 